\title{
ADRA1A wt Allele
}

National Cancer Institute

\section{Source}

National Cancer Institute. ADRA1A wt Allele. NCI Thesaurus. Code C51401.

Human ADRA1A wild-type allele is located within 8p21-p11.2 and is approximately $117 \mathrm{~kb}$

in length. This allele, which encodes alpha-1A adrenergic receptor protein, is involved in the regulation of smooth muscle contraction, cellular growth and proliferation. 